\title{
Work-Family Conflict of Women Entrepreneurs and Women Employees
}

\author{
Cicilia Larasati Rembulan and Kuncoro Dewi Rahmawati \\ Department of Psychology \\ Universitas Ciputra
}

\author{
Febe Yuanita Ratna Indudewi \\ International Business Management \\ Universitas Ciputra
}

\begin{abstract}
The aim of this study was to discover differences in work-family conflict among women who work as employees and women who worked as entrepreneurs. The samples of this research were 189 women (98 employees and 91 entrepreneurs). This quantitative comparative design used an incidental sampling technique. The measuring instrument was the work-family conflict (WFC) translated from Greenhaus and Beutell. The data collected was analyzed using Mann Whitney-U Test. The results show no difference in WFC among women who work as employees and women as entrepreneurs. However, the data shows that the majority of entrepreneur women has very low WFC in all aspects (time, strain, and behavior), while women who work as employees tend to have medium WFC. The results of cross tabulation show that there are indications of an association between revenue and WFC (time and strain aspects) in employee respondents. While the entrepreneur women show indication of an association between the ages of marriage, and duration of work with WFC.
\end{abstract}

Keywords: women, entrepreneur, employee, work-family conflict

Tujuan penelitian ini adalah untuk mengetahui perbedaan konflik kerja-keluarga atau workfamily conflict (WFC) antara perempuan yang bekerja sebagai karyawan dan perempuan yang bekerja sebagai entrepreneur/wiraswasta. Partisipan dalam penelitian ini 189 orang (98 karyawan dan 91 wiraswasta). Penelitian kuantitatif dengan desain komparatif ini menggunakan teknik sampling insidental. Alat ukur adalah work-family conflict (WFC) diterjemahkan dari Greenhaus dan Beutell. Analisis data menggunakan uji beda Mann Whitney-U Test. Hasil menunjukkan tidak ada perbedaan WFC antara perempuan yang bekerja sebagai karyawan dan perempuan wirausaha. Namun, data menunjukkan mayoritas wanita wirausaha memiliki WFC yang sangat rendah pada semua aspek (waktu, ketegangan, dan perilaku), sedangkan perempuan yang bekerja sebagai karyawan mayoritas WFCnya sedang. Hasil tabulasi silang menunjukkan bahwa pada karyawan ada indikasi asosiasi antara pendapatan dan WFC (aspek waktu dan aspek ketegangan). Adapun pada perempuan wirausaha terdapat indikasi asosiasi antara usia pernikahan dan WFC dan lama waktu bekerja dan WFC.

Keywords: perempuan, wiraswasta, karyawan, konflik kerja-keluarga

The modern woman is very different from the traditional woman. Higher levels of education enabled women to pursue careers in the public field. Many women hold positions of power such as being a mayor, president, minister, and other important positions. The changes occurring to women are linked with the gender equality movement suggested du-

Financial support from the Ministry of Research, Technology, and Higher Education through the Young Lecturers Research Grant 2015 is gratefully acknowledged.

Correspondence concerning this article should be addressed to Cicilia Larasati Rembulan, Universitas Ciputra, UC Town Citraland, Surabaya 60219. E-mail: cicilia.larasati.rembulan@gmail.com ring the period of R. A. Kartini. The Ministry of Women's Empowerment and Child Protection (Kementerian Pemberdayaan Perempuan dan Anak, 2012) stated that there has been an increase of women workers in the labour force. In 2004, the percentage of working women is $38.16 \%$, and it increased to $45.75 \%$ in 2011. This is pioneered by the education access equality between men and women. Statistics from the Center of Statistics (Badan Pusat Statistik, 2014) showed that the number of female entrepreneur is $5,590,638$, with a majority of them located in Java and Bali. This number showed a bigger increase compared to male entrepreneur. In 2012, there was only 
$7.80 \%$ increase of male entrepreneur, as compared to the $7.91 \%$ increase of female entrepreneur. On the other hand, the number of working women in Indonesia reached 1,200,241 in 2008, and increased by 288,614 in 2014.

A number of explanations include economic boosts, increased opportunity for women, and need to achieve self existence. Christine, Oktorina, and Mula (2010) explained that women work due to their need for self actualisation, especially following the completion of higher education. Working women have leverage and the power to get what they want (Zvonkovic, Schimiege, \& Hall, 1994). In addition, working women have better problem-solving skills due to their habit of solving problems in certain periods of time.

Despite the benefits of being a working woman, there's a dilemmatic impact of work to women. They often experience work-family conflict (WFC) which is the conflict of roles due to the imbalance of one domain to another. For example, in terms of time, a mother who needed to complete her professional work in the office has to take her child's school report. Another example is the aspect of strain, in this case a mother who is stressed out at work lashes out her anger to her child at home. The third example is behaviour conflict, with different role demands at home and in the office. WFC consisted of these three factors, which include time, strain, and behaviour (Greenhaus \& Beutel, 1985). There are more women who experience WFC compared to men. This is due to the traditional role of women as a homemaker and childbearer. Work pressure can only induce emotional fatigue, distress (lower performance) and turnover intention to leave work (Yavas, Babakus, \& Karatepe, 2008; Rantanen, Mauno, Kunnunen, \& Rantanen, 2011). K. L. Minotte, M. C. Minotte, Pedersen, Mannon, and Kiger (2010) stated that work-related distress can affect marital satisfaction. In a forum group discussion of eight working women (31 March 2015) it was shown that there was a lack of time and energy to live out two roles, lack of quality time with family, being inundated with work, more time for work than for family, work being carried over to their home so they have even less time for themselves. These things are in line with Rehman (2012) who stated that working women have life imbalance and work-family conflict, and they even have no time for themselves. For working women with child, this is especially dilemmatic because workplaces usually put rigid and unflexible rules regarding time schedules. They need to work for very long (Dolcos, 2006) so they can't fulfill their role as parents optimally. This situation can lead to parental dissatisfaction.

Alternative careers for women are to become entrepreneurs. The definition of an entrepreneur has been discussed in the literature. However, one of the most defining aspects of being an entrepreneur is their ability to work independently. In this case, the independence in question is their ability to organize their time and activities based on their own plans and design (Filion, 2011). Based on these definiteons, there seemed to be a good level of autonomy in terms of time and work activities on an entrepreneur. Minola, Criaco, and Obschonka (2016) stated that by working independently, someone usually have better autonomy and determination in working. Das (2001) explained that women who worked as an entrepreneur had lower levels of work-family conflict. By becoming an entrepreneur, a woman has the autonomy, personal satisfaction, and flexibility in managing time so they can arrange a time to take care of business and household related matters. Women can also reach the top level when she became an entrepreneur. The participation of women who worked as an entrepreneur is starting to become a trend in Asian countries. Based on personal interviews (March 13, 2015) with a woman entrepreneur engaged in the clothing business, it was stated that she enjoyed starting a business because it can help boost the economy of the family, especially after her husband has retired. Das (2001) explained that work-family conflict is not high on Indian women entrepreneurs.

In contrast to the earlier explanation, Basha, Pranav, Rao, Madhavi, and Sudha (2013) explained that women entrepreneurs also have a dual role in the community. The first role is taking care of the household and the second role is taking care of her business. Women still face work-family conflict. A woman who has a clothing business, in an interview (March 13, 2015) said that, when she was under stress she often scolded her son in front of her employees even though her son did nothing wrong. This was done when there was a lot of work to be handled so that became a pressure of its own. This showed the work-family conflict she faced. Research conducted in various developing countries such as Bangladesh, India, South Africa, and including Indonesia, showed the difficulties uniquely experienced by women entrepreneurs. Starting from the local customary law, such as culture and religion that limited the scope of movement of women and the difficult amount of household work for women with a family (Ahamad \& MoududUI-Hug, 2013; Ganesan, Kaur \& Maheshwari, 2002; 
Ragoobur \& Kasseeah, 2012). Moreover, in some countries, women's access to education is limited. This posed as a further obstacle for women to become enterpreneurs. Furthermore, there are more obstacles in the forms of capital constraints and the difficulty of accessing credit for women in developing countries. Kanungo (2003) mentioned the psychological side of women as an additional issue, including the lack of confidence and social structures that made women dependent on men. Entrepreneurs are often regarded as a masculine job, and as a woman there is an obligation to also be a mother and a wife (Chasserio, Pailo, \& Poroli, 2014). Women also lack the figure or role model that can inspire them to succeed as an entrepreneur.

Being a working woman as an employee or entrepreneur is not easy. There is a dilemmatic problem faced by women. Some literature explained that becoming an entrepreneur gave unique benefits as a woman, particularly in terms of schedule flexibility and decision making autonomy. However, there are still challenges that women have to face. For example, women in some countries chose to focus on one domain and ignore other domains by remaining single and focusing on her career (Bowen \& Hisrich as cited in Das, 2001). On the other hand, a number of women employee who focused on their family decided to leave their job (Yavas, Babakus, \& Karatepe, 2008). This showed the two sides of women's role that are not easy to do. On the one hand, they have autonomy, but on the other hand their role is difficult so most chose to focus on one role. From the Center of Statistics (Badan Pusat Statistik, 2010), 38.71\% of women in Jakarta chose to be single. That number increased in 2009 which is $38.07 \%$. If more women perceive that living as both working women and homemaker is difficult and they chose to be single, this can create an impact to a country's demographic structure.

The dilemmatic condition of working women needed to be attended to. The identification of work-family conflict phenomenon in women who work either as an employee or entrepreneur becomes an important issue to be discussed. With the identification of workfamily conflict faced by working women, it is expected to contribute knowledge to help women find better work and life balance. If women can lead balanced life, she could better contribute to the country by performing productively up to their own potential. When women are given support to have a balance between career and household, it could also affect the future generation. Children of working women can grow and develop properly and without losing a mother figure.
The earlier explanation showed that women who become employees or self-employed woman both equally experience difficulties by facing two roles in offices and households. They were equally required to meet both their roles. This caused a woman employee or entrepreneur to both experience workfamily conflict. However, on the other hand, there were some differences in the characteristics of employment and difficulties in women employees and entrepreneurs. These differences could possibly lead to differences in the level of work-family conflict experienced by both groups.

This research aimed to confirm the findings of previous studies that have been done in other countries about women's work as both entrepreneurs and employees, because past studies' evidence have not been conclusive. In particular, research on work-family conflict comparing the two groups of working women has not been done quantitatively. The few studies that have been done were conducted only in a specific group of samples. On one hand, researches on WFC to women entrepreneurs have been conducted by Ahamad and Moudud-UlHug (2013), Das (2001), and Ganesan, Kaur, and Maheshwari (2002); while research of the WFC on women employee has been studied by Annink, denDulk, and Stein (2016), Cohen (2009). None of the research so far has simultaneously investigated the comparison of work-family conflict between women who worked as an employee and as an entrepreneur. Therefore, the current research aimed to confirm previous research on whether there were different levels of work-family conflict on both women entrepreneurs and female employees. Although women entrepreneurs and employees both work professionally and are also housewives, the dynamics could be different. Women entrepreneurs who have work and time autonomy were predicted to have lower WFC compared to women who work as an employee.

This research will hopefully reveal the different of WFC levels between women employees and women entrepreneurs. Such findings could be an initial step to create a better support system for women who work, to improve the quality of their family. This will hopefully enable them to contribute better to the organization and to the country.

\section{Method}

This is a quantitative study with a comparative design. The sampling technique is a nonprobability sampling with incidental sampling. The population charac- 
teristic is married women who work on a full-time contract on an organisation and married women who work as entrepreneurs.

The subject consists of 189 women, 98 of whom were employees and 91 were entrepreneurs. Subjects were collected by distributing Work-Family Conflict Scale. The scale used was the one by Greenhaus and Beutell (Netemeyer, Boles, \& McMurrian, 1996) consisting of three aspects: strain, time, and behavior. Greenhaus and Beutell (Ahmad, 2008) explained WFC as three aspects. The first is a time-based conflict that occurs due to the time prioritized in one role making it difficult to participate in another role. The second type is strain-based conflict, which is a conflict of responsibility that occurs due to one role disrupting another. Lastly, behavior-based conflict occured due to behaviors that come with the responsibility in a role. Buck, Lee, MacDermid and Smith (Ahmad, 2008) stated that the reason why these conflicts occur was due to the limited energy that a woman has to conduct two roles at once. The questionnaire consisted of ten Likert-type scale items. Respondents were asked to indicate a number from 1 to 7 , where 1 indicated "Very Inappropriate" and 7 for "Very Appropriate" for each statement. All items in the scale are considered valid with a correlation level of .4 and reliability value of .881. An example of WFC time-aspect is "The time that I need to do my work makes it difficult for me to do family responsibilities". An example for WFC strain aspect is "The pressure in my work made it difficult for me to do household tasks". Lastly, WFC behavior-aspect included items such as "Demand from partner/family disrupts my work activities".

\section{Results}

\section{Demographics}

Subjects in this study are mostly 40-49 year olds ( $40.7 \%$ of total subjects). The highest level of education is bachelor/diploma (51.9\%), while the second highest is high school $(31.7 \%)$, while the rest vary between elementary school to masters. A total of 66 subjects $(34.9 \%)$ have been married for more than 20 years. These are the majority. There was an even spread of subjects who have been married for under five years $(17.5 \%)$, between 6-10 years $(14.8 \%)$, between $11-15$ years $(12.2 \%)$, and between $16-20$ years $(14.8 \%)$. The majority of subjects had to work or open a business for more than 15 years $(32.3 \%)$. A smaller number of subjects worked or opened a business for
12-15 years (7.4\%). In terms of weekly working hours, a majority of subjects worked for less than 50 hours, which are 41-50 hours per week (38.1\%) and less than 40 hours per week (32.8\%). A total of $40.2 \%$ of the subjects admitted that they rarely work overtime in their profession or business. While $29.1 \%$ said they never work overtime. Only $7.4 \%$ of the subjects stated that they frequently worked over time. In terms of income, a majority of subjects earned between three million to 5.9 million rupiahs per month (27\%). This is followed by subjects with monthly income above nine million (23.8\%) and income of one million to 2.9 million per month (23.3\%). Only $7.9 \%$ of the subjects had an income of below one million per month. Tables 1,2 , and 3 show the results of the demographic data of respondents of this study.

\section{Work-Family Conflict}

Table 4 indicates the descriptive statistics of subjects' WFC. The average score of all respondents WFC is 29.10, while the aspect of time at 9.62, strain aspects at 11.13 , and behavioral aspects at 8.35 . The minimum value that appears on subjects' WFC is 10 and the maximum 61 .

Table 5 showed the WFC levels of subjects. A total of 47 respondents $(24.9 \%)$ were categorised as having very low WFC. 49 respondents $(25.9 \%)$ had more WFC with low levels as the majority. In the medium category, there were 48 respondents $(25.4 \%)$ and in the high category there were 45 subjects $(23.8 \%)$.

On Table 6, the level of WFC on each aspect was shown. The majority of subjects are at a very low level $(29.1 \%)$ at the time aspect. Similarly, for the strain aspect, the majority of subjects were at a very low level $(33.9 \%)$. Behavioral aspects were categorised as very low $(37.0 \%)$.

\section{Comparison of WFC Between Female Employees and Female Entrepreneur}

Table 7 showed comparison results between female employees and female entrepreneur. Non-parametric test was used due to abnormal data. Mann WhitneyU test showed a significance value of .294. Thus, it can be concluded that there are no significant differences between employees and female entrepreneur.

\section{WFC Cross-tabulations on Female Employees and Female Entrepreneur}

Table 8 showed cross-tabulation results between WFC 
Table 1

Respondents' Demographics Data

\begin{tabular}{|c|c|c|c|}
\hline Data & Category & Total $(n)$ & $(\%)$ \\
\hline \multicolumn{4}{|l|}{ Age } \\
\hline & Less than 30 years old & 27 & 14.3 \\
\hline & 30-39 years old & 59 & 31.2 \\
\hline & $40-49$ years old & 77 & 40.7 \\
\hline & $50-59$ years old & 20 & 10.6 \\
\hline & More than 59 years old & 1 & 0.5 \\
\hline & Not indicated & 5 & 2.6 \\
\hline Total & & 189 & 100 \\
\hline \multicolumn{4}{|c|}{ Education } \\
\hline & Elementary School & 7 & 3.7 \\
\hline & Junior High School & 14 & 7.4 \\
\hline & High School & 60 & 31.7 \\
\hline & Bachelor/Diploma & 98 & 51.9 \\
\hline & Masters/higher & 8 & 4.2 \\
\hline & Not indicated & 2 & 1.0 \\
\hline Total & & 189 & 100 \\
\hline \multicolumn{4}{|c|}{ Duration of marriage } \\
\hline & Less than 5 years & 33 & 17.5 \\
\hline & $6-10$ years & 28 & 14.8 \\
\hline & $11-15$ years & 23 & 12.2 \\
\hline & $16-20$ years & 28 & 14.8 \\
\hline & More than 20 years & 66 & 34.9 \\
\hline & Not indicated & 11 & 5.8 \\
\hline Total & & 189 & 100 \\
\hline \multicolumn{4}{|c|}{ Work/business tenure } \\
\hline & $0-3$ years & 36 & 19.0 \\
\hline & 4-7 years & 41 & 21.7 \\
\hline & $8-11$ years & 33 & 17.5 \\
\hline & $12-15$ years & 14 & 7.4 \\
\hline & More than 15 years & 61 & 32.3 \\
\hline & Not indicated & 4 & 2.1 \\
\hline Total & & 189 & 100 \\
\hline \multicolumn{4}{|c|}{ Time spent at work/week } \\
\hline & Less than 40 hours & 62 & 32.8 \\
\hline & $41-50$ hours & 72 & 38.1 \\
\hline & 51-60 hours & 21 & 11.1 \\
\hline & More than 60 hours & 26 & 13.8 \\
\hline & Not indicated & 8 & 4.2 \\
\hline Total & & 189 & 100 \\
\hline \multicolumn{4}{|c|}{ Frequency of overtime work } \\
\hline & Very often & 14 & 7.4 \\
\hline & Often & 38 & 20.1 \\
\hline & Rarely & 76 & 40.2 \\
\hline & Never & 55 & 29.1 \\
\hline & Not indicated & 6 & 3.1 \\
\hline Total & & 189 & 100 \\
\hline \multicolumn{4}{|c|}{ Monthly income } \\
\hline & Less than 1 million & 15 & 7.9 \\
\hline & $1-2.9$ million & 44 & 23.3 \\
\hline & $3-5.9$ million & 51 & 27.0 \\
\hline & $6-8.9$ million & 29 & 15.3 \\
\hline & More than 9 million & 45 & 23.8 \\
\hline & Not indicated & 5 & 2.6 \\
\hline Total & & 189 & 100 \\
\hline
\end{tabular}

and the status of women as employee or entrepreneur. Results showed that there are no significant differences between employees and female entrepre-
Table 2

Demographics of Employee Respondents

\begin{tabular}{llrr}
\hline Data & \multicolumn{1}{c}{ Category } & Total $(n)$ & $(\%)$ \\
\hline Age & & & \\
& Less than 30 years old & 12 & 12.2 \\
& 30-39 years old & 32 & 32.7 \\
& 40-49 years old & 39 & 39.8 \\
& 50-59 years old & 10 & 10.2 \\
& More than 59 years old & 0 & 0 \\
& Not indicated & 5 & 5.1 \\
Total & & 98 & 100
\end{tabular}

Education

Elementary School

Junior High School

High School

Bachelor/Diploma

Masters/higher

Not indicated

Total

of Marriage

Duration of Marriage
Less than 5 years

6-10 years

11-15 years

16-20 years

Nore than 20 years

Total

Not indicated $\quad 11 \quad 11.2$

Work/business tenure

$\begin{array}{llr}0-3 \text { years } & 8 & 8.2\end{array}$

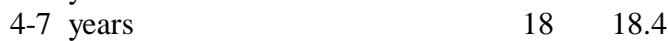

$\begin{array}{lll}8-11 \text { years } & 19 & 19.4\end{array}$

12-15 years $\quad 11 \quad 11.2$

More than 15 years $\quad 40 \quad 40.8$

$\begin{array}{lll}\text { Not indicated } & 2 & 2\end{array}$

Total

$\begin{array}{rr}2 & 98 \\ & 100\end{array}$

Time spent at work/week

Less than 40 hours $\quad 23 \quad 23.5$

41-50 hours $\quad 59 \quad 60.2$

51-60 hours $\quad 9 \quad 9.2$

More than 60 hours $\quad 4 \quad 4.1$

Not indicated $\quad 3 \quad 3.1$

$\begin{array}{lrr}\text { Total } & 98 & 100\end{array}$

Frequency of overtime work

$\begin{array}{lrr}\text { Very often } & 3 & 3.1 \\ \text { Often } & 18 & 18.4 \\ \text { Rarely } & 44 & 44.9 \\ \text { Never } & 30 & 30.6 \\ \text { Not indicated } & 3 & 3.1 \\ & 98 & 100\end{array}$

Total
Monthly income

\begin{tabular}{lrr} 
Less than 1 million & 6 & 6.1 \\
$1-2.9$ million & 25 & 25.5 \\
$3-5.9$ million & 31 & 31.6 \\
$6-8.9$ million & 19 & 19.4 \\
More than 9 million & 12 & 12.2 \\
Not indicated & 5 & 5.1 \\
& 98 & 100 \\
\hline
\end{tabular}

neurs. However, it can be seen on Table 8 that a majority of employees were categorized as medium. A majority of entrepreneurs fell on the low category, 
even though the difference was not significant.

\section{Cross-tabulations of WFC Results Between Entrepreneurs and Employees with Demo- graphics}

Cross tabulations were done as supplementary analyses. Based on the Pearson Chi-Square tabulation between demographics data and WFC categories, income had a $p$-value of .026. It can be concluded that there is a difference on WFC of female employees and entrepreneurs based on their income.

Table 9 showed that for those who earn less than one million, a majority had high WFC, while those who earn more than nine million fell onto the very low WFC category. Results can be seen in Table 8 .

\section{Cross Tabulations on Female Employee Data}

On the female employee data, the authors did cross tabulations between WFC and its aspects with demographics data. Results showed that only income had an association with time and strain aspects of WFC, but it was not directly associated with WFC. This means that higher income is associated with lower levels of WFC aspects of time and strain. Pearson Chi-square test showed a $p$-value of .033 on cross tabulations of income with time aspect, and a $p$-value .01 on cross tabulations between income and strain. Results are displayed on Table 10 and Table 11.

\section{Cross Tabulations on Female Entrepreneur Data}

Pearson Chi-Square cross tabulations were also done on female entrepreneur data with the demographics. Results indicated difference only on marriage duration and time spent at work with WFC in general. The $p$-value on cross tabulation between marriage duration and WFC is .00 whereas $p$-value on cross tabulation between time spent on work and WFC is .023. Seen from each aspect, only marriage duration had a significant association with each aspect of WFC ( $p$-value of .00 for all three aspects of WFC).

On Table 12, it can be seen that when marriage duration is less than five years, the majority of WFC is in the high category. Meanwhile, at higher marriage duration, like 16-20 years, the majority of WFC are in the very low category and at the marriage duration of more than 20 years the majority are in the low category WFC.

Seen from time spent at work, there is also a difference. Those who work under 40 hours a week, the
Table 3

Demographics of Entrepreneur Respondents

\begin{tabular}{|c|c|c|c|}
\hline Data & Category & Total $(n)$ & $(\%)$ \\
\hline \multicolumn{4}{|l|}{ Age } \\
\hline & Less than 30 years old & 15 & 16.5 \\
\hline & $30-39$ years old & 27 & 29.7 \\
\hline & $40-49$ years old & 38 & 41.8 \\
\hline & 50-59 years old & 10 & 11.0 \\
\hline & More than 59 years old & 1 & 1.1 \\
\hline & Not indicated & 0 & 0 \\
\hline Total & & 91 & 100 \\
\hline \multicolumn{4}{|c|}{ Education } \\
\hline & Elementary School & 6 & 6.6 \\
\hline & Junior High School & 13 & 14.3 \\
\hline & High School & 30 & 33.0 \\
\hline & Bachelor/Diploma & 38 & 41.8 \\
\hline & Masters/higher & 3 & 3.3 \\
\hline & Not indicated & 1 & 1.1 \\
\hline Total & & 91 & 100 \\
\hline \multicolumn{4}{|c|}{ Duration of Marriage } \\
\hline & Less than 5 years & 15 & 16.5 \\
\hline & $6-10$ years & 12 & 13.2 \\
\hline & $11-15$ years & 11 & 12.1 \\
\hline & $16-20$ years & 14 & 15.4 \\
\hline & More than 20 years & 39 & 42.9 \\
\hline & Not indicated & 0 & 0 \\
\hline Total & & 91 & 100 \\
\hline \multicolumn{4}{|c|}{ Work/business tenure } \\
\hline & $0-3$ years & 28 & 30.8 \\
\hline & 4-7 years & 23 & 25.3 \\
\hline & $8-11$ years & 14 & 15.4 \\
\hline & $12-15$ years & 3 & 3.3 \\
\hline & More than 15 years & 21 & 23.1 \\
\hline & Not indicated & 2 & 2.2 \\
\hline Total & & 91 & 100 \\
\hline \multicolumn{4}{|c|}{ Time spent at work/week } \\
\hline & Less than 40 hours & 39 & 42.9 \\
\hline & $41-50$ hours & 13 & 14.3 \\
\hline & $51-60$ hours & 12 & 13.2 \\
\hline & More than 60 hours & 22 & 24.2 \\
\hline & Not indicated & 5 & 5.5 \\
\hline Total & & 91 & 100 \\
\hline \multicolumn{4}{|c|}{ Frequency of overtime work } \\
\hline & Very often & 11 & 12.1 \\
\hline & Often & 20 & 22.0 \\
\hline & Rarely & 32 & 35.2 \\
\hline & Never & 25 & 27.5 \\
\hline & Not indicated & 3 & 3.3 \\
\hline Total & & 91 & 100 \\
\hline \multicolumn{4}{|c|}{ Monthly income } \\
\hline & Less than 1 million & 9 & 9.9 \\
\hline & $1-2.9$ million & 19 & 20.9 \\
\hline & $3-5.9$ million & 20 & 22.0 \\
\hline & $6-8.9$ million & 10 & 11.0 \\
\hline & More than 9 million & 33 & 36.2 \\
\hline & Not indicated & 0 & 0 \\
\hline Total & & 91 & 100 \\
\hline
\end{tabular}

majority of WFC is at very low category. Women entrepreneurs who work more than 60 hours per week, the majority fell in the category of high WFC. The tabulated results are presented in Table 12. 
Table 4

Respondent's Descriptive Statistics on WFC

\begin{tabular}{lrrrr}
\hline $\begin{array}{lrrr}\text { Desc. } \\
\text { Stat. }\end{array}$ & WFC & Time & Strain & Behavior \\
\hline Mean & 29.10 & 9.62 & 11.13 & 8.35 \\
Std. & 10.872 & 3.693 & 4.595 & 3.506 \\
Dev. & & & & \\
Min & 10 & 3 & 4 & 3 \\
Max & 61 & 21 & 28 & 18 \\
\hline Women & & & & \\
Employees & & & & \\
\hline Mean & 29.6 & 9.81 & 11.32 & 8.50 \\
& 2 & & & \\
Std. Dev. & 10.2 & 3.56 & 4.44 & 3.29 \\
& 6 & & & \\
Min & 10 & 3 & 4 & 3 \\
Max & 61 & 21 & 28 & 15 \\
\hline Women & & & & \\
Entrepreneurs & & & & \\
\hline Mean & 28.5 & 9.42 & 10.92 & 8.19 \\
& 3 & & & \\
Std. Dev. & 11.5 & 3.84 & 4.77 & 3.73 \\
Min & 2 & & & 3 \\
Max & 10 & 3 & 4 & \\
\hline
\end{tabular}

Table 5

Respondent's WFC Category

\begin{tabular}{lcr}
\hline WFC & Amount $(n)$ & $(\%)$ \\
Category & & \\
\hline Very low & 47 & 24.9 \\
Low & 49 & 25.9 \\
Medium & 48 & 25.4 \\
High & 45 & 23.8 \\
Total & 189 & 100 \\
\hline
\end{tabular}

\section{Discussion}

The purpose of this study was to determine differences in work-family conflict between women who work as employees and entrepreneurs. Work-family conflict occurs when a person is more focused and dedicated to one role only. It would lead to a time, strain, and behavior conflict. Results showed that there was no significant difference between both samples on their WFC levels. However, judging from the trend of the mean scores, female employees had higher WFC than women entrepreneurs. The majority of women who work as employees is in the category of medium WFC, while women who worked as an entrepreneur is in the very low category. This is in line with the research of Das (2001) who found that the WFC levels of female entrepreneur are not high,
Table 6

Respondent's WFC Category for Each Aspect

\begin{tabular}{lcr}
\hline Category & Amount $(n)$ & $(\%)$ \\
\hline Time Aspect & & \\
\hline Very low & 55 & 29.1 \\
Low & 40 & 21.2 \\
Medium & 54 & 28.6 \\
High & 40 & 21.2 \\
Total & 189 & 100 \\
\hline Strain aspect & & \\
\hline Very low & 64 & 33.9 \\
Low & 31 & 16.4 \\
Medium & 54 & 28.6 \\
High & 40 & 21.2 \\
Total & 189 & 100 \\
Behavior aspect & & \\
\hline Very low & 70 & 37.0 \\
Low & 33 & 17.5 \\
Medium & 46 & 24.3 \\
High & 40 & 21.2 \\
Total & 189 & 100 \\
\hline
\end{tabular}

Table 7

Comparison Test Between Female Employee and Female Entrepreneur

\begin{tabular}{lr}
\hline Comparison of WFC & Score \\
\hline Employee WFC average & 99.02 \\
Entrepreneur WFC average & 90.67 \\
Mann Whitney-U & 4065.00 \\
$Z$-score & -1.049 \\
$P$-value & 0.294 \\
\hline
\end{tabular}

and is similar to female employees. This contrasts with the research of Ufuk and Ozgen (2001), who explained that there is a high work-family conflict experienced by women entrepreneurs in Turkey.

Based on the results of additional cross-tabulation analyses, some aspects have been found to be associated with WFC on female employees. The first is an indication of an association between income and work-family conflict aspect of time. The data suggests that women who have an income of less than 1 million had a high category of WFC. Conversely, women who are earning more than nine million had low WFC. This is similar to that expressed by Ciabattari (2007) that low-income women experience higher levels of WFC compared to higher-income women. It was explained that lower income is also related to worse access to the support system. This is in line with Ryan and Sagas (2009) and Ford (2011) who stated that there was a correlation between employee satisfaction and high income on work-family conflict. In this case, higher income will be associated with lo- 
Table 8

Cross Tabulation Between Entrepreneurs and Employees With WFC

\begin{tabular}{|c|c|c|c|c|c|}
\hline \multirow{2}{*}{ Status } & \multicolumn{4}{|c|}{ Work-Family Conflict Category $(n)$} & \multirow{2}{*}{ Total $n(\%)$} \\
\hline & Very low $(\%)$ & Low $(\%)$ & Medium (\%) & High $(\%)$ & \\
\hline Female employee & $\begin{array}{c}21 \\
(21.4)\end{array}$ & $\begin{array}{c}25 \\
(25.5)\end{array}$ & $\begin{array}{c}28 \\
(28.6)\end{array}$ & $\begin{array}{c}24 \\
(24.5)\end{array}$ & $98(100)$ \\
\hline $\begin{array}{l}\text { Female } \\
\text { enterpreneur }\end{array}$ & $\begin{array}{c}26 \\
(28.5)\end{array}$ & $\begin{array}{c}24 \\
(26.5)\end{array}$ & $\begin{array}{c}20 \\
(21.9)\end{array}$ & $\begin{array}{c}21 \\
(23.1)\end{array}$ & $91(100)$ \\
\hline Total & $\begin{array}{c}47 \\
(24.8) \\
\end{array}$ & $\begin{array}{c}49 \\
(25.9)\end{array}$ & $\begin{array}{c}48 \\
(25.4) \\
\end{array}$ & $\begin{array}{c}45 \\
(23.8) \\
\end{array}$ & $189(100)$ \\
\hline
\end{tabular}

Table 9

Cross Tabulation Between Income With WFC

\begin{tabular}{|c|c|c|c|c|c|}
\hline \multirow{2}{*}{ Income } & \multicolumn{4}{|c|}{ Work-Family Conflict category $(n)$} & \multirow{2}{*}{ Total $n(\%)$} \\
\hline & Very low $(\%)$ & Low $(\%)$ & Medium $(\%)$ & $\operatorname{High}(\%)$ & \\
\hline Less than 1 million & $\begin{array}{c}0 \\
(0)\end{array}$ & $\begin{array}{c}3 \\
(20.0)\end{array}$ & $\begin{array}{c}4 \\
(26.7)\end{array}$ & $8(53.3)$ & $15(100)$ \\
\hline $1-2.9$ million & $\begin{array}{c}12 \\
(27.3)\end{array}$ & $15(34.1)$ & $10(22.7)$ & $7(15.9)$ & $44(100)$ \\
\hline $3-5.9$ million & $\begin{array}{c}10 \\
(19.6)\end{array}$ & $10(19.6)$ & $20(39.2)$ & $11(21.6)$ & $51(100)$ \\
\hline $6-8.9$ million & $\begin{array}{c}9 \\
(31.0)\end{array}$ & $\begin{array}{c}8 \\
(27.6)\end{array}$ & $\begin{array}{c}3 \\
(10.3)\end{array}$ & $9(31.0)$ & $29(100)$ \\
\hline $\begin{array}{l}\text { More than } 9 \\
\text { million }\end{array}$ & $\begin{array}{c}15 \\
(33.3)\end{array}$ & $\begin{array}{c}12 \\
(26.7)\end{array}$ & $10(22.2)$ & $8(17.8)$ & $45(100)$ \\
\hline Total & $\begin{array}{c}46 \\
(25.0)\end{array}$ & $48(26.1)$ & $47(25.5)$ & $43(23.4)$ & $184(100)$ \\
\hline
\end{tabular}

Table 10

Cross Tabulation Between Income and Time Aspect for Employees

\begin{tabular}{|c|c|c|c|c|c|}
\hline \multirow{2}{*}{ Income } & \multicolumn{4}{|c|}{ Time Aspect Category $(n)$} & \multirow{2}{*}{ Total $n(\%)$} \\
\hline & Very low $(\%)$ & Low $(\%)$ & Medium (\%) & High $(\%)$ & \\
\hline \multirow[t]{2}{*}{ Less than 1 million } & 0 & 0 & 4 & 2 & \\
\hline & (0) & (0) & $(66.7)$ & $(33.3)$ & $(100)$ \\
\hline \multirow[t]{2}{*}{$1-2.9$ million } & 7 & 6 & 7 & 5 & 25 \\
\hline & $(28.0)$ & $(24.0)$ & $(28.0)$ & $(20.0)$ & $(100)$ \\
\hline \multirow{2}{*}{$3-5.9$ million } & 5 & 4 & 12 & 5 & 31 \\
\hline & $(16.1)$ & $(29.0)$ & $(38.7)$ & $(16.1)$ & $(100)$ \\
\hline \multirow[t]{2}{*}{$6-8.9$ million } & 9 & 9 & 0 & 6 & 19 \\
\hline & $(47.4)$ & (21.1) & (0) & (31.6) & (100) \\
\hline More than 9 & 4 & 1 & 6 & 1 & 12 \\
\hline million & $(33.3)$ & $(8.3)$ & $(50.0)$ & $(8.3)$ & $(100)$ \\
\hline \multirow[t]{2}{*}{ Total } & 25 & 20 & 29 & 19 & 93 \\
\hline & (26.9) & (21.5) & $(31.2)$ & (20.4) & (100) \\
\hline
\end{tabular}

wer WFC. Antoniak (2011) also argued that when someone does not have a balance, then there is also a perception of time inequality. Employees in general, whether male or female, experienced a perception of inequity, where they feel that there is a difference between the salary they get and the activities of their actual work. That's why, even though they are highly paid, they still have high WFC (Bhave, Kramer, \& Glomb, 2012). The female employee could also expe- rience the same thing. However, this is not found on female entrepreneurs, presumably due to their autonomy on deciding work activities. On employees, work activities are usually determined and governed by a superior or standard procedure, so they are more likely to perceive their salaries to not match with the strain of the performance. While for the entrepreneur, they themselves design their work activities. They know how to earn money, so they do not feel the dif- 
Table 11

Cross Tabulation Between Income and Strain Aspect for Employees

\begin{tabular}{|c|c|c|c|c|c|}
\hline \multirow{2}{*}{ Income } & \multicolumn{4}{|c|}{ Strain Aspect Category $(n)$} & \multirow{2}{*}{ Total $n(\%)$} \\
\hline & Very low (\%) & Low $(\%)$ & Medium (\%) & $\operatorname{High}(\%)$ & \\
\hline \multirow[t]{2}{*}{ Less than 1 million } & 1 & 0 & 1 & 4 & \\
\hline & (16.7) & $(0,0)$ & (16.7) & $(66.7)$ & (100) \\
\hline \multirow[t]{2}{*}{$1-2.9$ million } & 4 & 10 & 6 & 5 & 25 \\
\hline & $(16.0)$ & $(40.0)$ & $(24.0)$ & $(20.0)$ & (100) \\
\hline \multirow[t]{2}{*}{$3-5.9$ million } & 6 & 6 & 13 & 6 & 31 \\
\hline & (19.4) & (19.4) & (41.9) & (19.4) & (100) \\
\hline \multirow[t]{2}{*}{$6-8.9$ million } & 11 & 2 & 3 & 3 & 19 \\
\hline & $(57.9)$ & $(10.5)$ & $(15.8)$ & $(15.8)$ & $(100)$ \\
\hline More than 9 & 5 & 1 & 4 & 2 & 12 \\
\hline million & $(41.7)$ & (8.3) & (33.3) & (16.7) & (100) \\
\hline \multirow[t]{2}{*}{ Total } & 27 & 19 & 27 & 20 & 93 \\
\hline & $(29.0)$ & $(20.5)$ & $(29.0)$ & $(21.5)$ & $(100)$ \\
\hline
\end{tabular}

Table 12

Cross Tabulation Between Marriage Duration and Time Spent Working With WFC of Entrepreneurs

\begin{tabular}{|c|c|c|c|c|c|}
\hline \multirow{2}{*}{ Demographics } & \multicolumn{4}{|c|}{ Work-Family Conflict Category ( $n$ ) } & \multirow{2}{*}{ Total $n(\%)$} \\
\hline & Very low (\%) & Low $(\%)$ & Medium (\%) & $\operatorname{High}(\%)$ & \\
\hline \multicolumn{6}{|l|}{ Marriage Duration } \\
\hline \multirow[t]{2}{*}{ Less than 5 years } & 3 & 3 & 4 & 5 & 15 \\
\hline & $(20.0)$ & $(20.0)$ & $(26.7)$ & $(33.3)$ & $(100)$ \\
\hline \multirow[t]{2}{*}{$6-10$ years } & 2 & 3 & 4 & 3 & 12 \\
\hline & $(16.7)$ & $(25.0)$ & $(33.3)$ & $(25.0)$ & (100) \\
\hline \multirow[t]{2}{*}{$11-15$ years } & 4 & 4 & 1 & 2 & 11 \\
\hline & $(36.4)$ & $(36.4)$ & $(9.1)$ & $(18.2)$ & $(100)$ \\
\hline \multirow[t]{2}{*}{$16-20$ years } & 6 & 1 & 3 & 4 & 14 \\
\hline & $(42.9)$ & (7.1) & (21.4) & (28.6) & (100) \\
\hline \multirow{2}{*}{$\begin{array}{l}\text { More than } 20 \\
\text { years }\end{array}$} & 11 & 13 & 8 & 7 & 39 \\
\hline & $(28.2)$ & (33.3) & $(20.5)$ & $(17.9)$ & (100) \\
\hline \multirow[t]{2}{*}{ Total } & 26 & 24 & 20 & 21 & 91 \\
\hline & $(28.5)$ & $(26.4)$ & $(22.0)$ & $(23.1)$ & $(100)$ \\
\hline \multicolumn{6}{|c|}{ Time Spent Working } \\
\hline \multirow[t]{2}{*}{ Less than 40 hours } & 14 & 9 & 10 & 6 & 39 \\
\hline & (35.9) & $(23.1)$ & $(25.6)$ & $(15.4)$ & (100) \\
\hline \multirow[t]{2}{*}{$41-50$ hours } & 0 & 2 & 7 & 4 & 13 \\
\hline & $(0.0)$ & (15.4) & $(53.8)$ & $(30.8)$ & $(100)$ \\
\hline \multirow[t]{2}{*}{$51-60$ hours } & 4 & 5 & 0 & 3 & 12 \\
\hline & (33.3) & (41.7) & $(0.0)$ & $(25.0)$ & $(100)$ \\
\hline \multirow{4}{*}{$\begin{array}{l}\text { More than } 60 \\
\text { hours } \\
\text { Total }\end{array}$} & 6 & 7 & 2 & 7 & 22 \\
\hline & $(27.3)$ & $(31.8)$ & $(9.1)$ & $(31.8)$ & $(100)$ \\
\hline & 24 & 23 & 19 & 20 & 86 \\
\hline & (27.9) & $(26.7)$ & $(22.1)$ & $(23.3)$ & $(100)$ \\
\hline
\end{tabular}

ference in income and performance like the employee.

In addition, there is an association between income and work-family conflict aspects of strain. The results showed indications of an association between income and WFC aspects of strain. Particularly, the higher the income, the lower the WFC aspect of strain. Conversely, lower income will be associated with higher WFC aspect of strain. Modie-Moroka (2014) noted that pressure or strain can arise from an adaptive response to the environment. A working woman who does not earn enough will feel pressured to meet the daily needs of her family, making it possible for her to feel depressed. This is particularly important in recent times where living cost is high.

Based on two cross tabulation analysis results earlier, it can be seen that income showed indicated association of work-family conflict aspects of time as well as with strain. This is contrary to previous statements 
by $\mathrm{Ku}$ (1991) who explained that income is often associated with career commitments. Someone who earn low wages, have a tendency to quit. On the other hand, this is contrary to the research conducted by Bhave, Kramer, and Glomb (2012), who explained that although real income is important, the perception of income satisfaction is even more important. An individual who has a high income may not be satisifed with her salary. Such dissatisfaction might cause a high work-family conflict.

Based on supplementary cross-tabulation analysis, some aspects have been noted to have an association with WFC on entrepreneurs:

(1) Association between marriage duration with work-family conflict. Based on the data, those who have been married for less than five years had high WFC, whereas those with higher duration of marriage (more than 16 years) had low WFC. This is in line with VanLaningham, Johnson, and Amato (2016) who stated that those in the early stages of marriage experience difficulties due to negotiating responsibilities and have to face conflicts. In contrast, those who have been married for longer were happier compared to those who only recently married. Marriage duration is correlated with happiness due to perceived financial stability, the presence of a home base, and approaching retirement. It is possible that the birth of a child will create financial or time demand which will lead to stress/pressure for parents. Mulyandini, Lelly, \& Tobing (2015) stated that the first 1-3 years is a risky period in marriage, where problems usually occur and each partner enter an adaptation process. Therefore, longer marriage duration will lead to being more stable in facing challenges.

(2) Association between time spent at work with work-family conflict. Based on the data it can be seen that the group of women entrepreneurs who work under 40 hours a week, the majority were categorized at WFC of very low category. Whereas women entrepreneurs who work more than 60 hours per week, the majority were categorized as high WFC. Annink, denDulk, and Stein (2016) said that working as an entrepreneur was also associated with long working hours, intensive work, job demands, job stress, and financial insecurity. The factors that contribute to workfamily conflict were the long work period and the high workload. Major, Klein, and Ehrhart (2002) noted that time spent at work was positively correlated with work-family conflict. Nowadays, people feel hastier than 30 years ago. Long working time can contribute to the emergence of negative consequences. Conflicts can occur when a person is focused on one role. Long working hours are associated with an increase in work-family conflict aspect of time. Long working hours are also associated with increased depression or psychosomatic symptoms. This is in line with the research by Adkin and Premeaux (2012) who said that time spent at work has a linear correlation with work-family conflict, especially with the less flexible work time (Ciabbattari, 2007). Anafarta (2010) also stated a similar argument where there is a correlation between the working hours of employees with workfamily conflict, in this case more working hours will lead to greater WFC experienced.

In essence, women who chose to be an entrepreneur is not motivated by financial incentives, but mainly try to find a new life goal separate from her old environment. Dzisi (as cited in Cohen, 2009) stated that women decide to do their own business to boost family economy, because they were frustrated by their past work, wanting to show achievement, and to fill up their time. Meng and Liang (1996, as cited in Cohen) added the desire to grow as another motivation to become an entrepreneur. They want to have flexibility and control of their life and to independently develop. Thus, money is not the only thing for entrepreneur women, and indeed autonomy and selfdevelopment are considered as important aspects. Working period designed to match their own work activity gives a sense of work satisfaction, as well as decrease family conflict.

On the other hand, women who choose to be employees have a greater motivation for money compared to entrepreneurs. For married women, there is pressure to balance work demands with family demands. Van der Lipe (2005, as cited in Cohen, 2009) stated that working women need to be supported in their specific problems. Not only through social support, but also for example by helping them provide care for their children (e.g., with a day care), or to support their family income by providing incentives.

\section{Limitations}

There are some limitations in the process of this study. Initially, the researcher did not hold the level of responsibility equally between employees and entrepreneurs. This may affect the results because both respondents may not have equal position and income. The authors did not put a marriage duration limit for the subjects. The results can be very different if such limit was applied. Some studies have shown that marriage duration affects WFC. Early years of marriage tend to be associated with higher WFC, and vice 
versa. Had the researcher put this limit in place, the effect of this factor will be controlled. From data analysis perspective, the analysis method is too simple with utilizing comparative tests and cross tabulations. Further research can be done using more sophisticated methods of analysis such as SEM and Path. From research design perspective, the results of this study are merely quantitative. A mixed method (quantitative and qualitative) should enrich the results to enable the development of personal story and meaning of life as a homemaker and worker from the perspective of respondents. The study can also be developed from the respondent side. Cultural difference in addressing women employee or entrepreneurs can cause the differing levels of WFC. For example, a culture that is more open to the role of women as workers or entrepreneurs will result in lower levels of WFC.

\section{Conclusion}

Work-family conflict is the role dilemma that occurs due to an imbalance between one domain and another (Yavas et al., 2008), which consists of the conflict in time, strain, and behaviour. Until recently, many researchers have studied the work-family conflict on women who either work as an employee or as an entrepreneur. The result is not conclusive because it was said that being an employee lead to women having higher WFC. Research has led to the mapping of conflicts experienced by working women or women who are self-employed. For example, a study of female nurses in Israel showed that problems arise mostly from occupational factors rather than families. This suggested that job-related variables such as job description and salary brought conflict into their households (Cohen, 2009). On the other hand, there are studies showing that female entrepreneurs also have a higher WFC.

Results showed no significant difference on WFC between entrepreneurs and employees. However, it can be seen that the WFC of entrepreneurs tend to be lower than employees. A factor indicated to be associated with WFC on employees is income, especially WFC concerning time aspect and strain. Higher income was associated with lower levels of both WFC concerning the time and strain aspects. For entrepreneurs, marriage duration and time spent at work were indicated to be associated with WFC. This is related to the difference in work characteristics, where entrepreneurs have more autonomy in regulating their own work and income, so income does not significantly affect WFC of female entrepreneurs.
Although this study revealed that women who work as either an employee or an entrepreneur had low to medium levels of WFC, preventative measures should still be done. By devising a good support system for working women, this can improve the physical and psychological health of women. A woman with good physical and psychological health will be able to provide optimal care for her family and children and working women can still achieve self actualization.

\section{References}

Adkin, C. L., \& Premeaux, S. F. (2012). Spending time: The impact of hours worked on work-family conflict. Journal of Vocational Behavior, 80, 380-389.

Ahamad, I., \& Moudud-UI-Hug, S. (2013). Women entrepreneurship in Bangladesh challenges and prospects. International Journal of Innovative Research and Development, 2(7), 41-48.

Ahmad, A. (2008). Job, family, and individual factors as predictors of work-family conflict. The Journal of Human Resource and Adult Learning, 4(1), 57-65.

Anafarta, N. (2010). The relationship between workfamily conflict and job satisfaction: A Structural equation model (SEM) Approach. International Journal of Business and Management, 6, 168-177.

Annink, A., denDulk, L., \& Stein, B. (2016). Workfamily conflict among employees and the self employed across Europe. [online]. Retrieved from http://www.ncbi.nlm.nih.gov/pmc/articles/PMC4 751170/

Antoniak, E. (2011). Time perspective and job satisfaction in professionals oriented towards people and towards objects. Human Resource Management \& Ergonomics, 5, 1-13.

Badan Pusat Statistik. (2010). Laju pertumbuhan penduduk. Retrieved from https://www.bps.go.id/ Subjek/view/id/12\#subjekViewTab3|accordiondaftar-subjek1

Badan Pusat Statistik. (2014). Persentase Penduduk menurut Provinsi dan Jenis Kelamin tahun 20092012: Sosial dan Kependudukan. Retrieved from http://www.bps.go.id/tab_sub/view.php?kat=1\&t abel $=1 \&$ daftar $=1 \&$ id_subyek $=40 \&$ notab $=1 /$

Basha, A. M., Pranav, S., Rao, N. R. V. S. S., Madhavi, K., \& Sudha, P. S. (2013). A study on the development of women entrepreneurship in Nellore, AP, India. Research Journal of Management Sciences, 2, 1-5. 
Bhave, D. P., Kramer, A., \& Glomb, T. M. (2012). Pay satisfaction and work-family conflict across time. Journal of Organizational Behavior, 34(5), 698-713.

Chasserio, S., Pailo. P., \& Poroli. C. (2014). When entrepreneurial identity meets multiple social identities. Interplays and identity work of women entrepreneurs. International Journal of Entrepreneurial Behavior \& Research, 20, 128-154.

Christine, W. S., Oktorina, M., \& Mula, I. (2010). Pengaruh konflik pekerjaan dan konflik keluarga terhadap kinerja dengan konflik pekerjaan keluarga sebagai intervening variabel: Studi pada dual career couple di Jabodetabek. Jurnal Manajemen dan Kewirausahaan, 12, 121-132.

Ciabattari, T (2007). Single mothers, social capital, and work-family conflict. Journal of Family Issues, 28(1), 34-60.

Cohen, A. (2009). Work-family conflict among female employees in Israeli hospitals. Personnel Review, 38(2), 124-141.

Das, M. (2001). Women entrepreneurs from India: Problems, motivations and success factors. Journal of Small Business and Entrepreneurship, 15 (4), 67-82.

Dolcos, S. M. (2006). Understanding family business relationship: Preserving the family in business. The Family Journal, 8, 351-359.

Filion, L. J. (2011) Defining the entrepreneur. In L. P. Dana (Ed.), World encyclopedia of entrepreneurship (pp. 41-52). Cheltenham, UK and Northampton, MA: Edward Elgar.

Ford, M. T (2011). Linking household income and work-family conflict: A moderated mediation study. Stress and Health, 27, 144-162.

Ganesan, R., Kaur, D., \& Maheshwari, R. (2002). Women entrepreneurs: Problems and prospects. Journal Entrepreneurship, 11(75), 75-93. http:// dx.doi. org/10.1177/097135570201100105

Greenhaus, J. H. \& Beutell, N. J. (1985). Sources of conflict between work and family roles. Academy of Management Review, 10(1), 76-88.

Kanungo, R. (2003). Entrepreneurship and innovation models for development. New Delhi: Sage Publication, Inc.

Kementerian Pemberdayaan Perempuan \& Perlindungan Anak (2012). Pembangunan manusia berbasis gender. Jakarta: CV Permata Andika.

$\mathrm{Ku}, \mathrm{M}$. (1991). An examination of work-family conflict and intention to leave among college and university food service managers (Unpublished Doctoral Dissertation). Faculty of The Graduate Col- lege of The Oklahoma State University, Oklahoma.

Major, V. S., Klein, K. J., Ehrhart, M. G. (2002). Work time, work interference with family and psychological distress. Journal of Applied Psychology, 87, 427-436.

Minola, T., Criaco, G., \& Obschonka, M. (2016). Age, culture, and self employment motivation. Small Business Economy, 46, 187-213.

Minnote, K. L., Minnote, M. C., Pedersen, D. E., Mannon, S. E., \& Kiger, G. (2010). His and her perspectives: Gender ideology, work to family conflict and marital satisfaction. Sex Roles, 63, 425-438.

Modie-Moroka, T. (2014). Stress, social relationship and health outcomes in low income Francistown, Bostwana. Social Psychiatry Epidemiology, 49, 1269-1277.

Mulyandini, A. D., Lelly, S. W., Tobing, D. S. K. (2015). Self efficacy sebagai mediasi pengaruh work-family conflict dan iklim kerja terhadap kinerja karyawan perbankan. Artikel ilmiah mahasiswa Universitas Jember. Retrieved from http:// repository.unej.ac.id

Netemeyer, R. G., Boles., J. S., \& McMurrian, R. (1996). Development and validation of workfamily conflict and family work conflict scales. Journal of Applied Psychology, 81, 400-410.

Ragoobur, V., \& Kasseeah, H. (2012). Unveiling the profile of women entrepreneurs in the small island economy of mauritius. Interdisciplinary Journal of Contemporary Research in Business, 4(4), 437-449.

Rantanen, M., Mauno, S., Kunnunen, U., \& Rantanen, J. (2011). Do individual coping strategies help or harm in the work-family conflict situation? Examining coping as a moderator between work-family conflict and well being. International Journal of Stress Management, 18, 24-48.

Rehman, S. M. A. R. (2012). Gender and work life balance: A phenomenological study of women entrepreneurs in Pakistan. Journal of Small Business and Enterprise Development, 19(2), 209-228.

Ryan, T. D., \& Sagas, M. (2009). Relationships between pay satisfaction, work-family conflict and coaching turnover intention. Team Performance Management: An International Journal, 15, 128-140.

Ufuk, H., \& Ozgen, O. (2001). Interaction between the business and family lives of women entrepreneurs in Turkey. Journal of Business Ethics, 31, 95-106.

VanLaningham, J., Johnson, D. R., \& Amato, P. (2016). Marital happiness, marital duration, and 
the u-shaped curve. Evidence from a five wave panel study. Social Forces, 78, 1313-1341.

Yavas, U., Babakus., \& Karatepe, O. M. (2008). Attitudinal and behavioral consequences of workfamily conflict and family work conflict: Does gen- der matter? International Journal of Service Industry Management, 19, 7-31.

Zvonkovic, A. M., Schmiege, C. J., \& Hall, L. D. (1994). Influence strategies used when couples make work-family decision. Family relations, 43, 182-188. 